\title{
Cobalt(II), Nickel(II), Copper(II), and Zinc(II) Complexes with a p-tert- Butylcalix[4]arene Fitted with Phosphinoyl Pendant Arms
}

\author{
Vladimira Videva, ${ }^{[a]}$ Anne-Sophie Chauvin, ${ }^{[b]}$ Sabi Varbanov, ${ }^{[c]}$ Christophe Baux ${ }^{[b]}$ \\ Rosario Scopelliti, ${ }^{[b]}$ Mariana Mitewa, ${ }^{[a]}$ and Jean-Claude G. Bünzli*[b]
}

Keywords: Calix[4]arene / Transition metals / Stability constants / X-ray diffraction / Polynuclear compounds

A series of complexes of $\mathrm{M}^{\mathrm{II}} \mathrm{X}_{2}$ transition metal salts ( $\mathrm{X}=$ $\left.\mathrm{ClO}_{4}, \mathrm{M}=\mathrm{Co}, \mathrm{Ni}, \mathrm{Cu}, \mathrm{Zn} ; \mathrm{X}=\mathrm{Cl}, \mathrm{M}=\mathrm{Cu}, \mathrm{Zn}\right)$ with a calix[4]arene substituted at the lower rim $\{\mathrm{L}=5,11,17,23$-tetratert-butyl-25,26,27,28-tetrakis[(dimethylphosphinoyl)methoxy]calix[4]arene\} are isolated and characterized. Two different stoichiometries are evidenced, 1:1 for the $\mathrm{Co}^{\mathrm{II}}, \mathrm{Ni}^{\mathrm{II}}$, and $\mathrm{Cu}^{\mathrm{II}}$ complexes, independently of the anion $\left(\mathrm{Cl}^{-}\right.$or $\left.\mathrm{ClO}_{4}^{-}\right)$, as well as for the $\mathrm{Zn}\left(\mathrm{ClO}_{4}\right)_{2}$ complex, while a 2:1 metal/ligand ratio is found for the complex with $\mathrm{ZnCl}_{2}$. The coordination mode and structure of the complexes are investigated by several spectroscopic and magnetochemical methods, both in the solid state and in solution. Coordination through the phosphoryl groups of the ligand is ascertained by X-ray diffraction and IR and NMR spectroscopic data. The crystal structure of the 2:1 Zn compound (triclinic, $P \overline{1}, Z=2$ ) shows the presence of the tetrametallic species $\mathrm{Zn}_{4} \mathrm{~L}_{2}$ with three different tetrahedral $\mathrm{Zn}$ environments, $\mathrm{ZnCl}_{2} \mathrm{O}_{2}$, $\mathrm{ZnCl}_{3} \mathrm{O}$, and $\mathrm{ZnClO}_{3}$, the latter bridging two ligand molecules. Magnetic susceptibility, EPR data, and electronic spectra are indicative of a tetrahedral arrangement of the ligands in the $\mathrm{Co}^{\mathrm{II}}$ (high-spin $\mathrm{d}^{7}$ ) 1:1 complex, which is also most probably the ligand geometry in the $\mathrm{Ni}^{\mathrm{II}}$ and $\mathrm{Cu}^{\mathrm{II}} 1: 1 \mathrm{com}$ plexes. In solution, the extent of the interaction between $\mathrm{L}$ and the $\mathrm{M}^{\mathrm{II}}$ ions has been determined by UV/Vis spectrophotometric titrations. The resulting stability constants for 1:1 complexes are in the range log $K_{1}=4.8-5.4$.

(c) Wiley-VCH Verlag GmbH \& Co. KGaA, 69451 Weinheim, Germany, 2004)

\section{Introduction}

During the last decade, a great deal of interest has been devoted to the design of functionalized calixarenes in view of their excellent coordination and extraction properties. ${ }^{[1-4]}$ Phosphorus-containing calixarenes have proven particularly useful in the separation of lanthanides and actinides. ${ }^{[5]}$ Moreover, transition metal complexes with calixarenes are good models for mimicking biological processes. ${ }^{[6]}$ For example, $\mathrm{Co}^{\mathrm{II}}$ or $\mathrm{Cu}^{\mathrm{I} / \mathrm{II}}$ complexes can be used to transport and activate small molecules of biological interest, such as dioxygen, and/or for studying the catalytic effect of copper enzymes in non-aqueous solvents. ${ }^{[7 a]}$ Other applications lie in analytical chemistry, as recently reported for calixarene-based luminescent sensors for $\mathrm{Cu}^{\mathrm{II}}{ }^{[7 \mathrm{~b}]}$ and $\mathrm{Zn}^{\mathrm{II}},{ }^{[7 \mathrm{c}]}$ for instance. In the recent past, we have reported the synthesis of narrower-rim substituted $p$-tert-butylcalix$[n]$ arenes fitted with either ether-amide $\left(n=4,{ }^{[8 \mathrm{a}]} 6^{[8 \mathrm{~b}]}\right)$ or

[a] University of Sofia, Department of Chemistry, 1126 Sofia, Bulgaria

[b] Laboratory of Lanthanide Supramolecular Chemistry, BCH 1402, Swiss Federal Institute of Technology,

1015 Lausanne, Switzerland

[c] Institute of Polymers, Bulgarian Academy of Sciences, 1113 Sofia, Bulgaria

Supporting information for this article is available on the WWW under http://www.eurjic.org or from the author. phosphinoyl groups $\left[n=4(\mathrm{~L}),{ }^{[8 c]} 6^{[4]}\right]$. In particular, the thermodynamic and photophysical properties of the 1:1 and 1:2 (metal/ligand) complexes of $\mathrm{L}$ (see scheme) with trivalent lanthanide ions $\left(\mathrm{La}^{\mathrm{III}}, \mathrm{Eu}^{\mathrm{III}}, \mathrm{Tb}^{\mathrm{III}}\right)$ were studied in detail. ${ }^{[8 c]}$ The ligand itself adopts a flattened cone conformation and a $\Delta$-enantiomeric form which should also be quite convenient for the binding of $3 \mathrm{~d}$ transition metal ions forming tetracoordinated species. In this paper we therefore investigate the coordination ability of $\mathrm{L}$ towards $\mathrm{Co}^{\mathrm{II}}, \mathrm{Ni}^{\mathrm{II}}$, $\mathrm{Cu}^{\mathrm{II}}$ and $\mathrm{Zn}^{\mathrm{II}}$ perchlorates, as well as the structural properties of the resulting isolated complexes. Influence of the anion on the stoichiometry of the complexes is tested for $\mathrm{Cu}^{\mathrm{II}}$ and $\mathrm{Zn}^{\mathrm{II}}$ by replacing perchlorate with chloride.

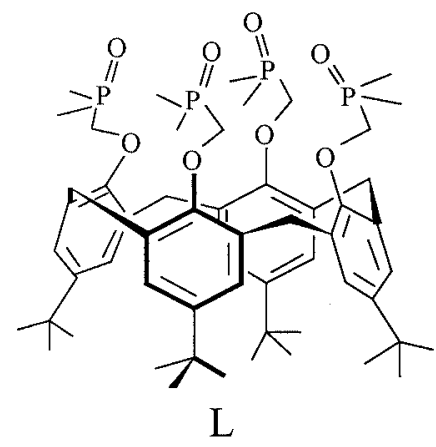




\section{Results and Discussion}

\section{Isolation of the Complexes and Solid-State Properties}

The complexes were isolated from ethanolic solutions and elemental analyses are consistent with the formation of compounds with a 1:1 metal/ligand stoichiometry: $\mathrm{M}\left(\mathrm{ClO}_{4}\right)_{2} \mathrm{~L} \cdot 2 \mathrm{H}_{2} \mathrm{O} \quad[\mathrm{M}=\mathrm{Co}$ (1), Ni (2), $\mathrm{Zn}$ (5); $\mathrm{Cu}\left(\mathrm{ClO}_{4}\right)_{2} \mathrm{~L} \cdot 4 \mathrm{H}_{2} \mathrm{O}(3)$, and $\mathrm{CuCl}_{2} \mathrm{~L} \cdot 4 \mathrm{H}_{2} \mathrm{O}$ (4)], while a compound with a $2: 1(\mathrm{M} / \mathrm{L})$ stoichiometric ratio was isolated with zinc chloride: $\mathrm{Zn}_{2} \mathrm{Cl}_{4} \mathrm{~L}$ (6). IR spectroscopic data (Table S1, Figure S1, Supporting Information) are consistent with an interaction taking place through the $\mathrm{P}=\mathrm{O}$ groups of the ligand. In the free ligand, the $\mathrm{P}=\mathrm{O}$ stretching vibration appears as an intense split band with components at 1160 and $1171 \mathrm{~cm}^{-1}$, pointing to inequivalent phosphoryl groups. In the chloride complexes $\left(1: 1, \mathrm{Cu}^{\mathrm{II}}\right.$ and $2: 1$, $\mathrm{Zn}^{\mathrm{II}}$ ) this band undergoes a further splitting leading to the observation of $3\left(\mathrm{Zn}^{\mathrm{II}}, 2: 1\right.$ complex $)$ and $4\left(\mathrm{Cu}^{\mathrm{II}}, 1: 1 \mathrm{com}-\right.$ plex) components, all of them being red-shifted with respect to those of the free ligand. That is, the $\mathrm{P}=\mathrm{O}$ groups become more inequivalent in the complexes; as a matter of fact, the crystal structure of the $\mathrm{Zn}^{\mathrm{II}} 2: 1$ complex (vide infra) shows three types of $\mathrm{P}=\mathrm{O}$ groups, coordinated to monodentate $\mathrm{ZnCl}_{3}{ }^{-}$, bidentate bridging $\mathrm{ZnCl}_{2}$ and tridentate bridging $\mathrm{ZnCl}^{+}$units. The shift of the more intense component with respect to the ligand, $\Delta \tilde{v} \approx 50 \mathrm{~cm}^{-1}$, is considerably larger than the one reported for $\mathrm{ZnCl}_{2}\left(\mathrm{Ph}_{3} \mathrm{PO}\right)_{2}{ }^{[9]}$ or for zinc halide adducts with (aminomethyl)dimethylphosphane ox$\operatorname{ide}^{[10]}$ (ca. $35 \mathrm{~cm}^{-1}$ ), pointing to a stronger interaction with the metal ion, despite the fact that chloride ions remain coordinated. Analysis of the $\mathrm{P}=\mathrm{O}$ vibrations for the $1: 1$ perchlorate complexes is not easy in view of the overlap with the perchlorate modes. The spectra of all complexes are relatively similar, with three components in the ranges $1104-1109,1121-1123$ and $1143-1144 \mathrm{~cm}^{-1}$ (the middle component is not seen in the spectrum of the $\mathrm{Co}^{\mathrm{II}}$ complex). The shifts are difficult to determine since the more intense band does not correspond to the same components in the various spectra, but they range between 27 and 60 $\mathrm{cm}^{-1}$, again indicating a substantial interaction between the phosphoryl groups and the metal ions. Several vibrations are seen in the $627-636 \mathrm{~cm}^{-1}$ range, so that the presence of non-ionic (possibly coordinated) perchlorate ions cannot be ruled out. For instance, in $\left[\mathrm{Co}\left(\mathrm{ClO}_{4}\right)(\text { topo })_{4}\right] \mathrm{ClO}_{4}$ (topo $=$ trioctylphoshane oxide) in which perchlorate anions are coordinated, $\Delta \tilde{v}(\mathrm{P}=\mathrm{O}) \approx 30 \mathrm{~cm}^{-1}$. [11]

In order to obtain additional information about the geometrical arrangement of the ligating atoms in the paramagnetic complexes, susceptibility measurement and EPR spectra have been recorded for $\mathrm{Co}^{\mathrm{II}}, \mathrm{Ni}^{\mathrm{II}}$ and $\mathrm{Cu}^{\mathrm{II}}$ (Figure 1), as well as electronic spectra. The effective magnetic moment $\mu_{\text {eff }}$ of the $\mathrm{Co}^{\mathrm{II}}$ complex amounts to 5.0 B.M. at room temperature and is temperature-dependent, which is typical of a high-spin $\mathrm{d}^{7}$ complex with either octahedral or tetrahedral ligand arrangements. The relatively large value of $\mu_{\text {eff }}$ could be more consistent with an octahedral arrangement (reported values are in the range 4.7-5.2 B.M., while fourcoordinate high-spin compounds have $\mu_{\mathrm{eff}}$ in the range
4.2-4.9 B.M. $\left[4.76\right.$ B.M. for $\left(\mathrm{Ph}_{3} \mathrm{PO}\right)_{2} \mathrm{CoCl}_{2}$, for instance]. ${ }^{[12]}$ On the other hand, the intense blue color of the complex points to the latter being more likely tetrahedral. ${ }^{[13]}$ Reasoning in terms of idealized symmetries, a tetrahedral arrangement generates three spin-allowed transitions, ${ }^{4} \mathrm{~A}_{2} \rightarrow{ }^{4} \mathrm{~T}_{2},{ }^{4} \mathrm{~T}_{1}(\mathrm{~F}),{ }^{4} \mathrm{~T}_{1}(\mathrm{P})$; the latter is situated between 600 and $650 \mathrm{~nm}$ and is usually the more intense, while the other two transitions are in the NIR range $(1-2 \mu \mathrm{m})$. Octahedral $\mathrm{d}^{7}$ complexes also display three $\mathrm{d}-\mathrm{d}$ transitions ${ }^{4} \mathrm{~T}_{1 \mathrm{~g}}(\mathrm{~F}) \rightarrow{ }^{4} \mathrm{~T}_{1 \mathrm{~g}}(\mathrm{P}),{ }^{4} \mathrm{~A}_{2 \mathrm{~g}},{ }^{4} \mathrm{~T}_{2 \mathrm{~g}}$ the first being the more intense one and occurring between 500 and $600 \mathrm{~nm}$; it often appears as being split because the ${ }^{4} \mathrm{~A}_{2 \mathrm{~g}}$ level is close to ${ }^{4} \mathrm{~T}_{1 \mathrm{~g}}(\mathrm{P})$; the transition to ${ }^{4} \mathrm{~T}_{2 \mathrm{~g}}$ occurs in the NIR region; generally speaking these transitions are about one order of magnitude less intense than the transitions of the tetrahedral complexes. ${ }^{[13]}$ In our case, the reflectance spectrum displays two weak d-d transitions at 473 and $516 \mathrm{~nm}$, a main component at $597 \mathrm{~nm}$, and two additional broad and very weak bands at 916 and ca. $1450 \mathrm{~nm}$. In $\mathrm{CH}_{3} \mathrm{CN}$ solution $\left(2.7 \times 10^{-3} \mathrm{M}\right.$, Figure 2$)$, the corresponding bands appear at 454(86) $(\varepsilon=$ $\left.112 \mathrm{M}^{-1} \cdot \mathrm{cm}^{-1}\right), 515(11), 586(65)$, and $1407(55) \mathrm{nm}$. The relatively large values of the molar absorption coefficients are more in line with a tetrahedral arrangement of the ligands; the latter appears to be severely distorted, leading to a low symmetry, henceforth the observation of several transitions in the range $450-600 \mathrm{~nm}$ [splitting of the ${ }^{4} \mathrm{~T}_{1}(\mathrm{P})$ level]. The effective magnetic moment of the $\mathrm{Ni}^{\mathrm{II}}$ complex at room temperature is equal to $3.1 \mathrm{~B} . \mathrm{M}$. and is temperature-independent, down to about $30 \mathrm{~K}$. For a hexacoordinate, octahedral complex, a value between 2.9 and 3.4 B.M. is expected, while tetrahedral complexes have $\mu_{\text {eff }}$ in the range

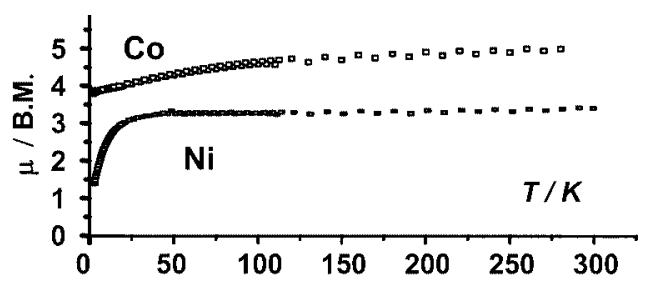

Figure 1. Temperature dependence of the effective magnetic moment of the $\mathrm{Co}^{\mathrm{II}}$, and $\mathrm{Ni}^{\mathrm{II}}$ complexes

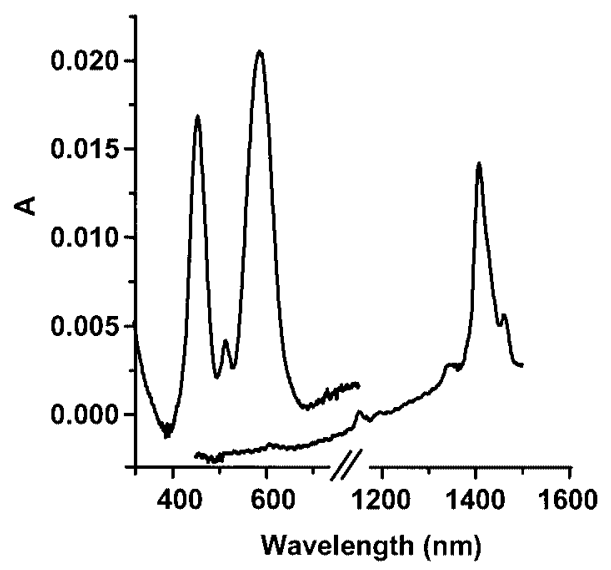

Figure 2. Parts of the electronic spectrum of $\mathrm{CoL}\left(\mathrm{ClO}_{4}\right)_{2} \cdot 2 \mathrm{H}_{2} \mathrm{O}$, $2.7 \times 10^{-3} \mathrm{M}$ in $\mathrm{CH}_{3} \mathrm{CN}$ 
$3.0-3.5$, if they are severely distorted, or 3.5-4.0 B.M., if they are less distorted. ${ }^{[12,13]}$ The value we find for the calixarene complex is therefore clearly compatible with either one of the first two situations. The reflectance spectrum displays a band at $446 \mathrm{~nm}$, with two shoulders on the low energy side and a weak one at $905 \mathrm{~nm}$ and is therefore compatible with a tetrahedral coordination. While $\mathrm{Co}^{\mathrm{II}}$ and $\mathrm{Ni}^{\mathrm{II}}$ complexes are EPR-silent, the $\mathrm{Cu}^{\mathrm{II}}$ chloride compound exhibits a single anisotropic line with $g=2.13 \pm 0.01$, both at room and low $(130 \mathrm{~K})$ temperatures, again consistent with a distorted tetrahedral coordination geometry.

Crystals of complex $\mathbf{6}$ have been obtained by slow concentration of a methanolic solution of $\mathrm{L}$ and $\mathrm{ZnCl}_{2}$ (each $10^{-3} \mathrm{M}$ ) and its solid-state structure has been elucidated by $\mathrm{X}$-ray diffraction. The structure is comprised of discrete units encompassing two molecules of ligand linked to four $\mathrm{Zn}^{\mathrm{II}}$ cations. The coordination of the metal ions is tetrahedral, even if the nature of the coordinating atoms differ (Figure 3): $\mathrm{Zn} 1$ is coordinated by one chloride anion and three oxygen atoms from phosphinoyl arms belonging to two calixarenes, thus creating a bridge between them; $\mathrm{Zn} 2$ and $\mathrm{Zn} 4$ are coordinated by two chloride anions and two oxygen atoms from neighboring phosphinoyl arms on the same ligand; $\mathrm{Zn} 3$ is coordinated by three chloride anions and only one oxygen atom from the last phosphinoyl arm. The mean $\mathrm{P}=\mathrm{O}$ bond length, 1.51(1) $\AA$, is in the range expected for $\mathrm{P}=\mathrm{O}$ double bonds, although this distance is larger than the one observed in the free ligand $(1.483 \AA) \cdot{ }^{[8 c]}$ The lengthening of the $\mathrm{P}=\mathrm{O}$ bond upon coordination is consistent with the red-shift observed for the $\tilde{v}(\mathrm{P}=\mathrm{O})$ vibration. The $\mathrm{Zn}-\mathrm{Cl}$ bond lengths are comparable for the four zinc atoms $[2.237(6) \AA]$, while the $\mathrm{Zn}-\mathrm{O}$ distance ranges from 1.92(1) to 2.01(1) $\AA$. The two different donor atoms around the $\mathrm{Zn}^{\mathrm{II}}$ ions generate distorted tetrahedral coordination polyhedra, essentially with respect to the $\mathrm{Ln}-\mathrm{X}$ distances; angles deviate less than $10^{\circ}$ from the ex- pected tetrahedral value (Table S2, Supporting Information). The two calixarenes adopt a typical flattened cone conformation (Table S3, Supporting Information) with two opposite phenolic units almost parallel to each other while the other two are approximately at right angles.

\section{Solution Properties of the Complexes}

The complexes have also been characterized in solution. Electrospray mass spectrometry (ES-MS) confirms that the metal:ligand ratios are maintained in solution (Table 1).

The corresponding spectra display peaks due to the free ligand as $[\mathrm{L}]^{+},[\mathrm{L}+2 \mathrm{H}]^{2+}$ species in addition to the expected cations $[\mathrm{L}+\mathrm{Co}]^{2+},[\mathrm{L}+\mathrm{Ni}]^{2+},[\mathrm{L}+\mathrm{Cu}]^{2+},[\mathrm{L}+$ $\mathrm{Zn}]^{2+}$. Hydrated ligand species are also seen in the case of $\mathbf{3}, \mathbf{5}$ and $\mathbf{6}$, but only the spectrum of $\mathbf{5}$ presents peaks attributable to a hydrated metal ion $\left(\mathrm{Zn}^{\mathrm{II}}\right)$. For complexes 1-5, dissociation of the complexes occurs according to Equations (1) and (2).

$\mathrm{MLX}_{2} \rightarrow \mathrm{L}+\mathrm{MX}_{2}$

$\mathrm{MLX}_{2} \rightarrow[\mathrm{ML}]^{2+}+2 \mathrm{X}^{-}$

Spectra of the dimetallic $\mathrm{Zn}^{\mathrm{II}}$ complex $\mathbf{6}$, have been recorded in both positive and negative modes and the following species were unambiguously identified: $[\mathrm{ZnL}]^{2+}$, $[\mathrm{ZnCl}(\mathrm{L})]^{+},\left[\mathrm{Zn}_{2} \mathrm{Cl}(\mathrm{L})\right]^{3+}$ and $\left[\mathrm{ZnCl}_{3}\right]^{-}$. The presence of these species, particularly the negatively charged trichloride, leads to the hypothesis that the complex in solution may be formulated as $[\mathrm{ZnCl}(\mathrm{L})]\left[\mathrm{ZnCl}_{3}\right]$. The dimetallic species is more difficult to account for. One may think that dissolution of the tetrametallic complex characterized by X-ray diffraction results in a reorganization of the $\mathrm{Zn} 1$ and $\mathrm{Zn} 3$ coordination sphere to give monomeric dimetallic complexes $\mathrm{Zn}_{2} \mathrm{Cl}_{4} \mathrm{~L}$ with each metal ion coordinated to two chloride ions and two phosphoryl groups. However, spectrophotometric titrations (vide infra) point to the sole pres-

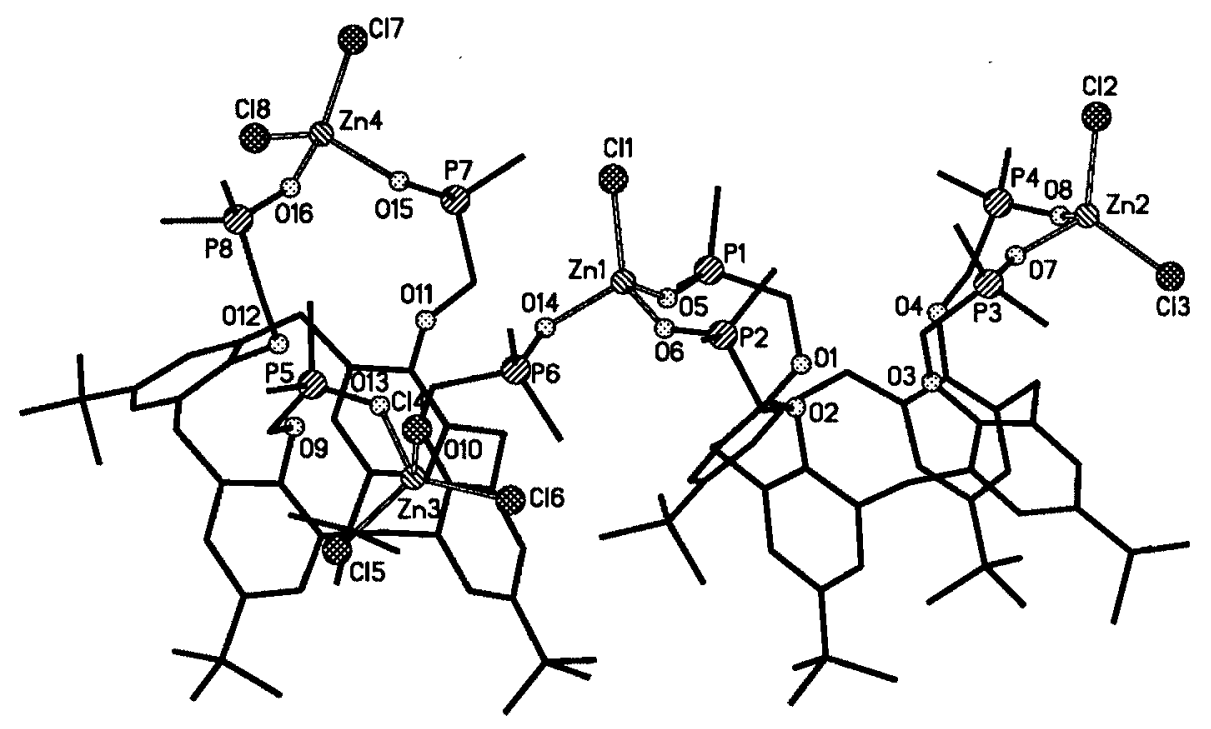

Figure 3. Ball-and-stick representation of the crystal structure of $\mathbf{6}$ showing the atom-numbering scheme for all atoms but carbon atoms (hydrogen atoms and external water molecules are not shown while the size of carbon atoms has been reduced to zero for the sake of clarity) 
Table 1. Molecular peaks and main fragments observed by ES-MS analysis (positive and negative modes) for the complexes of $\mathbf{L}$

\begin{tabular}{|c|c|c|c|c|}
\hline Compound (No.) & Mol. mass & Species & Obsd. $m / z$ & Calcd. $m / z$ \\
\hline $\mathrm{L}$ & 1009.17 & {$[\mathrm{~L}]^{+}$} & 1009.80 & 1009.17 \\
\hline $\mathrm{CoL}\left(\mathrm{ClO}_{4}\right)_{2} \cdot 2 \mathrm{H}_{2} \mathrm{O}$ & \multirow[t]{4}{*}{1303.05} & {$[\mathrm{Co}+2 \mathrm{~L}+6 \mathrm{H}]^{8+}$} & 260.27 & 260.36 \\
\hline \multirow[t]{3}{*}{1} & & {$[\mathrm{~L}+\mathrm{Co}]^{2+}$} & 534.00 & 534.05 \\
\hline & & {$[\mathrm{L}+2 \mathrm{H}]^{2+}$} & 505.86 & 505.59 \\
\hline & & {$[\mathrm{L}+\mathrm{H}]^{+}$} & 1009.79 & 1010.17 \\
\hline \multirow{6}{*}{$\begin{array}{l}\mathrm{NiL}\left(\mathrm{ClO}_{4}\right)_{2} \cdot 2 \mathrm{H}_{2} \mathrm{O} \\
\mathbf{2}\end{array}$} & \multirow[t]{6}{*}{1302.79} & {$\left[\mathrm{~L}+\mathrm{Ni}+3 \mathrm{H}+4 \mathrm{CH}_{3} \mathrm{OH}\right]^{5+}$} & 240.29 & 239.80 \\
\hline & & {$\left[\mathrm{L}+\mathrm{Ni}+3 \mathrm{H}+7 \mathrm{CH}_{3} \mathrm{OH}\right]^{5+}$} & 259.31 & 259.03 \\
\hline & & {$[\mathrm{L}+\mathrm{Ni}]^{2+}$} & 533.38 & 533.93 \\
\hline & & {$\left[\mathrm{L}+\mathrm{Ni}+\mathrm{CH}_{3} \mathrm{CN}\right]^{2+}$} & 554.36 & 554.45 \\
\hline & & {$[\mathrm{L}+2 \mathrm{H}]^{2+}$} & 505.86 & 505.58 \\
\hline & & {$[\mathrm{L}+\mathrm{H}]^{+}$} & 1009.86 & 1010.17 \\
\hline \multirow{3}{*}{$\begin{array}{l}\mathrm{CuL}\left(\mathrm{ClO}_{4}\right)_{2} \cdot 4 \mathrm{H}_{2} \mathrm{O} \\
3\end{array}$} & \multirow[t]{3}{*}{1303.05} & {$[\mathrm{~L}+2 \mathrm{H}]^{2+}$} & 505.82 & 505.58 \\
\hline & & {$\left[\mathrm{L}+2 \mathrm{H}+\mathrm{H}_{2} \mathrm{O}\right]^{2+}$} & 524.32 & 523.58 \\
\hline & & {$[\mathrm{L}+\mathrm{Cu}]^{2+}$} & 536.98 & 536.79 \\
\hline \multirow{3}{*}{$\begin{array}{l}\mathrm{CuLCl}_{2} \cdot 4 \mathrm{H}_{2} \mathrm{O} \\
\mathbf{4}\end{array}$} & \multirow[t]{3}{*}{1215.69} & {$[\mathrm{~L}+\mathrm{Cu}]^{2+}$} & 536.22 & 536.36 \\
\hline & & {$[\mathrm{L}+2 \mathrm{H}]^{2+}$} & 505.86 & 505.58 \\
\hline & & {$[\mathrm{L}+\mathrm{H}]^{+}$} & 1009.86 & 1010.17 \\
\hline \multirow{4}{*}{$\underset{5}{\mathrm{ZnL}}\left(\mathrm{ClO}_{4}\right)_{2} \cdot 2 \mathrm{H}_{2} \mathrm{O}$} & \multirow[t]{4}{*}{1309.48} & {$\left[\mathrm{~L}+4 \mathrm{H}+\mathrm{H}_{2} \mathrm{O}\right]^{4+}$} & 257.25 & 257.79 \\
\hline & & {$\left[2 \mathrm{~L}+\mathrm{Zn}+2 \mathrm{H}+\mathrm{H}_{2} \mathrm{O}\right]^{4+}$} & 524.33 & 524.43 \\
\hline & & {$[\mathrm{L}+\mathrm{Zn}]^{2+}$} & 537.28 & 537.28 \\
\hline & & {$[\mathrm{L}+\mathrm{H}]^{+}$} & 1009.27 & 1010.27 \\
\hline \multirow{9}{*}{$\begin{array}{l}\mathrm{Zn}_{2} \mathrm{LCl}_{4} \\
6\end{array}$} & \multirow[t]{9}{*}{1281.76} & {$\left[\mathrm{~L}+\mathrm{Zn}+2 \mathrm{H}+\mathrm{CH}_{3} \mathrm{CN}\right]^{4+}$} & 279.38 & 279.40 \\
\hline & & {$[\mathrm{L}+2 \mathrm{Zn}+\mathrm{Cl}]^{3+}$} & 391.35 & 391.79 \\
\hline & & {$[\mathrm{L}+2 \mathrm{H}]^{2+}$} & 505.82 & 505.78 \\
\hline & & {$\left[\mathrm{L}+2 \mathrm{H}+2 \mathrm{H}_{2} \mathrm{O}\right]^{2+}$} & 524.32 & 523.58 \\
\hline & & {$[\mathrm{L}+\mathrm{Zn}]^{2+}$} & 536.32 & 537.28 \\
\hline & & {$[\mathrm{L}+\mathrm{H}]^{+}$} & 1009.86 & 1010.17 \\
\hline & & {$[\mathrm{L}+\mathrm{Zn}+\mathrm{Cl}]^{+}$} & 1109.80 & 1110.00 \\
\hline & & {$[\mathrm{Zn}+3 \mathrm{Cl}]^{-}$} & 171.73 & 172.82 \\
\hline & & {$[\mathrm{L}+2 \mathrm{Zn}+10 \mathrm{Cl}]^{6-}$} & 248.84 & 249.08 \\
\hline
\end{tabular}

ence of 1:1 species in solution, so that the dimetallic species probably forms under the electrospray conditions, when the droplets evaporate.

The ${ }^{1} \mathrm{H}$ and ${ }^{31} \mathrm{P}\left\{{ }^{1} \mathrm{H}\right\}$ NMR spectroscopic data obtained for the free ligand and its $\mathrm{Zn}^{\mathrm{II}}$ complex in $\left[\mathrm{D}_{6}\right] \mathrm{DMSO}$ are reported in Table 2. Although the latter occurs within a fast exchange process, the coordination mode in solution through the phosphoryl groups is confirmed: both ${ }^{1} \mathrm{H}$ and ${ }^{31} \mathrm{P}\left\{{ }^{1} \mathrm{H}\right\}$ NMR shifts are affected by the complexation. The signal of the $\mathrm{CH}_{3} \mathrm{P}(\mathrm{O})$ protons is shifted by $\Delta \delta=$ $0.06-0.11 \mathrm{ppm}$. Large ${ }^{31} \mathrm{P}$ shifts are observed for the coordinated phosphoryl groups: $\Delta \delta=4.27 \mathrm{ppm}$, from 36.81 for the free ligand to $41.08 \mathrm{ppm}$ for $\mathrm{ZnL}\left(\mathrm{ClO}_{4}\right)_{2} \cdot 2 \mathrm{H}_{2} \mathrm{O}$, and $\Delta \delta=7.98 \mathrm{ppm}$, to $44.79 \mathrm{ppm}$ for the $\mathrm{Zn}_{2} \mathrm{LCl}_{4}$ complex 6 .
Analogous ${ }^{31} \mathrm{P}$ chemical shifts are measured in $\mathrm{CD}_{3} \mathrm{OD}$ : $\Delta \delta=2.69 \mathrm{ppm}$ for $\mathbf{5}$ and $\Delta \delta=6.08 \mathrm{ppm}$ for $\mathbf{6}$.

On the other hand, the difference in chemical shifts between $\mathbf{5}$ and $\mathbf{6}$, with $\Delta \delta(\mathbf{6}-\mathbf{5})=3.71 \mathrm{ppm}$, strongly suggests that the species in solution are quite different. Addition of 1 equiv. of tetramethylammonium chloride or zinc chloride directly to the solution containing $\mathrm{ZnL}\left(\mathrm{ClO}_{4}\right)_{2}$, followed by heating of the NMR tube for $2 \mathrm{~min}$, for solubility reasons, results in the observation of only one peak in the ${ }^{31} \mathrm{P}\left\{{ }^{1} \mathrm{H}\right\}$ spectrum, at $\delta=44.30 \mathrm{ppm}$, meaning that complex $5 \mathrm{im}$ mediately evolves into $\mathbf{6}$ upon chloride addition. Despite that the ratio of $\mathrm{Zn} / \mathrm{L} / \mathrm{Cl}$ not being the same (1:1:1 upon addition of $\mathrm{Me}_{4} \mathrm{NCl}$ and 2:1:2 upon addition of $\mathrm{ZnCl}_{2}$ ), the same species forms.

Table 2. ${ }^{1} \mathrm{H}$ and ${ }^{31} \mathrm{P}\left\{{ }^{1} \mathrm{H}\right\}$ NMR spectroscopic data of $[\mathrm{ZnL}]\left(\mathrm{ClO}_{4}\right)_{2} 2 \mathrm{H}_{2} \mathrm{O}(5)$ and $\left[\mathrm{Zn}_{2} \mathrm{~L}\right] \mathrm{Cl}_{4}(6)$ in $\left[\mathrm{D}_{6}\right] \mathrm{DMSO}$

\begin{tabular}{llllllllll}
\hline Compound $^{[\mathrm{a}]}$ & $\begin{array}{l}\mathrm{CH} \mathrm{H}_{3} \mathrm{P}(\mathrm{O}) \\
\delta[\mathrm{ppm}]\end{array}$ & $J_{\mathrm{H}, \mathrm{P}}[\mathrm{Hz}]$ & $\begin{array}{l}\mathrm{C} H_{2} \mathrm{P}(\mathrm{O}) \\
\delta[\mathrm{ppm}]\end{array}$ & $\begin{array}{l}\mathrm{Ar}-\mathrm{CH} H_{2}-\mathrm{Ar} \\
\delta[\mathrm{ppm}]\end{array}$ & ${ }^{2} J_{\mathrm{H}, \mathrm{H}}[\mathrm{Hz}]$ & $\begin{array}{l}\mathrm{Ar}-H \\
\delta[\mathrm{ppm}]\end{array}$ & $\begin{array}{l}\mathrm{C}\left(\mathrm{CH} H_{3}\right)_{3} \\
\delta[\mathrm{ppm}]\end{array}$ & $\begin{array}{l}P=\mathrm{O}[\mathrm{ppm}] / \Delta \delta[\mathrm{ppm}] \\
\delta[\mathrm{ppm}] / \Delta \delta[\mathrm{ppm}]\end{array}$ \\
\hline $\mathrm{L}$ & $1.43(\mathrm{~d})$ & 12.80 & $4.53(\mathrm{bs})$ & $3.19(\mathrm{~d}), 4.72(\mathrm{~d})$ & $12.80,12.80$ & $6.80(\mathrm{~s})$ & $1.04(\mathrm{~s})$ & $+36.81(\mathrm{~s}) /-$ & $+43.63(\mathrm{~s}) /-$ \\
$\mathbf{5}$ & $1.49(\mathrm{~d})$ & 13.16 & $4.56(\mathrm{bs})$ & $3.24(\mathrm{~d}), 4.65(\mathrm{~d})$ & $12.80,12.80$ & $6.82(\mathrm{~s})$ & $1.05(\mathrm{~s})$ & $+41.08(\mathrm{~s}) / 4.27$ & $+46.32 / 2.69$ \\
$\mathbf{6}$ & $1.54(\mathrm{~d})$ & 13.16 & $4.59(\mathrm{bs})$ & $3.25(\mathrm{~d}), 4.65(\mathrm{~d})$ & $12.80,12.80$ & $6.84(\mathrm{~s})$ & $1.05(\mathrm{~s})$ & $+44.79(\mathrm{~s}) / 7.98$ & $+49.71(\mathrm{~s}) / 6.08$ \\
\hline
\end{tabular}

${ }^{[a]}$ Key: bs: broad singlet; d: doublet; s: singlet. ${ }^{[b]}$ In $\mathrm{CD}_{3} \mathrm{OD}$. 


\section{Interaction of $\mathrm{L}$ with $\mathrm{Co}^{\mathrm{II}}, \mathrm{Ni}^{\mathrm{II}}, \mathrm{Cu}^{\mathrm{II}}$ and $\mathrm{Zn}^{\mathrm{II}}$ in Acetonitrile}

To assess the strength of the calixarene-metal interaction, we have determined stability constants in acetonitrile or acetonitrile containing a small amount of dichloromethane by spectrophotometric titrations of dilute solutions of L by the metal perchlorates $\mathrm{M}\left(\mathrm{ClO}_{4}\right)_{2} \cdot 6 \mathrm{H}_{2} \mathrm{O}(\mathrm{M}=\mathrm{Cu}, \mathrm{Zn})$ and chlorides $\mathrm{MCl}_{2} \cdot n \mathrm{H}_{2} \mathrm{O}(\mathrm{M}=\mathrm{Co}, \mathrm{Ni}, n=6 ; \mathrm{M}=\mathrm{Cu}$, $n=2 ; \mathrm{M}=\mathrm{Zn}, n=0$ ), at $25{ }^{\circ} \mathrm{C}$. For solubility reasons, no supporting electrolyte could be added. Figure 4 shows a typical example of such a titration. Data were analyzed by Specfit ${ }^{[14]}$ and factor analysis gave only two absorbing species for all the systems studied while absorbance versus metal/ligand ratios $R$ displayed breaks at $R=1$ (Figure S2, Supporting Information), so that under the experimental conditions used, only 1:1 complexes are formed, in line with the NMR spectroscopic data discussed above. The results reported in Table 3 show that the thermodynamic stability of the complexes is moderate, $\log K_{1}$ being in the range 4.2-5.4 and increasing slightly with increasing charge density of the metal ions. For zinc and copper complexes, stability constants were determined both with perchlorate and chloride salts to assess the influence of the anion. Only slight differences were obtained, which lie within experimental errors. The fact that perchlorate salts were hexahydrated $(\mathrm{M}=\mathrm{Cu}, \mathrm{Zn})$ also has to be taken into account: the presence of water molecules can interfere with the formation of the $\mathrm{M}\left(\mathrm{ClO}_{4}\right)_{2} \mathrm{~L}$ complexes while analogous titrations with chloride salts were performed with less hydrated salts $(\mathrm{Cu}, \mathrm{Zn})$. In contrast, much larger stability constants are

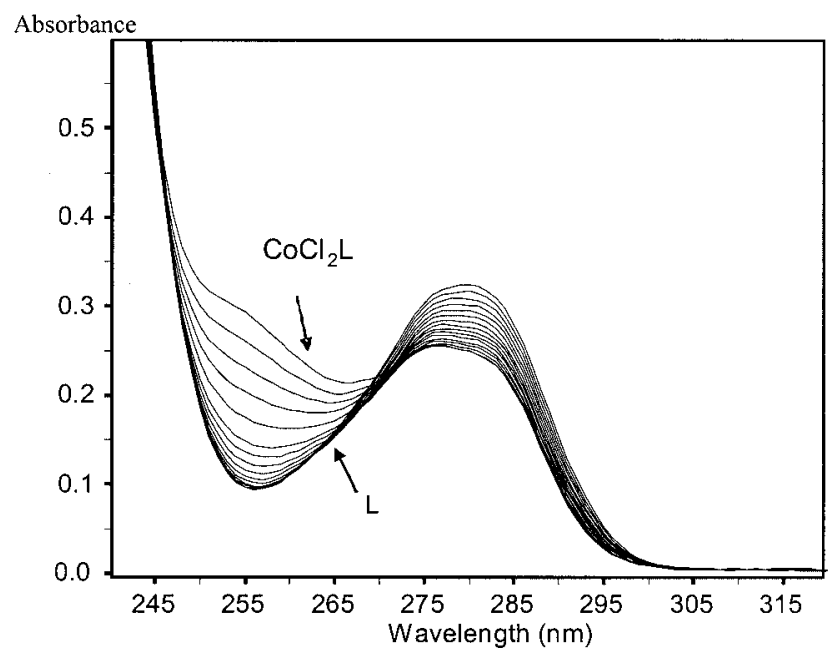

Figure 4. Variation of the absorption spectra observed during the spectrophotometric titration of $[\mathrm{L}]=9.51 \times 10^{-5} \mathrm{M}$ with $\left[\mathrm{CoCl}_{2} \cdot 6 \mathrm{H}_{2} \mathrm{O}\right]=1.01 \times 10^{-3} \mathrm{M}$ reported for the 1:1 and 1:2 complexes formed with lanthanum perchlorate, e.g. $11.4 \pm 1.5\left(\log K_{1}\right)$ and $19.6 \pm 1.8$ $\left(\log \beta_{2}\right),{ }^{[8 c]}$ this much larger stability can be traced back to the larger positive charge borne by the lanthanide cations.

\section{Conclusion}

The lower-rim phosphinoyl-substituted calix[4]arene L interacts with divalent $3 \mathrm{~d}$ transition metal ions $\mathrm{M}^{\mathrm{II}}(\mathrm{M}=$ $\mathrm{Co}, \mathrm{Ni}, \mathrm{Cu}$ and $\mathrm{Zn}$ ) to yield reasonably stable $1: 1$ complexes in ethanol. Isolated complexes also display 1:1 stoichiometry, except in the case of the $\mathrm{Zn}^{\mathrm{II}}$ chloride system for which a tetrametallic species crystallizes, which could be characterized by X-ray crystallography. Both IR and ${ }^{31} \mathrm{P}$ NMR spectroscopic data show the coordination of phosphoryl groups through strong $\mathrm{M}^{\mathrm{II}}-\mathrm{O}=\mathrm{P}$ bonds. Magnetochemical measurements and optical spectra cannot be interpreted unambiguously, but most of the reported features point to a tetrahedral arrangement of the ligands around $\mathrm{Co}^{\mathrm{II}}$ (high-spin $\mathrm{d}^{7}$ ), $\mathrm{Ni}^{\mathrm{II}}$ and $\mathrm{Cu}^{\mathrm{II}}$. In view of the ligand conformation, tetrahedral coordination of the four phosphoryl groups can be ruled out, so that the coordination sphere of the metal ions probably contains either 1-2 water molecules and/or chloride or perchlorate ions. We note that magnetic susceptibility data are consistent with isolated and non-interacting magnetic centers, which means that if polymetallic species are also present in the isolated $\mathrm{Co}$, or $\mathrm{Ni}$ complexes, such as those evidenced in $\left[\mathrm{Zn}_{2} \mathrm{Cl}_{4} \mathrm{~L}\right]_{2}$ (6), the metal-metal distances are large enough (cf. 7.8-11 $\AA$ in 6) to prevent magnetic interaction.

\section{Experimental Section}

Solvent and Starting Materials: The ligand was obtained as described previously. ${ }^{[8 c]}$ The metal salts were analytically pure and purchased from Fluka AG and Aldrich. All reagents and solvents were research grade and were used without further purification.

Caution: Perchlorate salts combined with organic ligands are potentially explosive and should be handled in small quantities and with adequate precautions. ${ }^{[15]}$

\begin{abstract}
Analytical and Physico-Chemical Measurements: Elemental analyses were performed by Dr H. Eder from the Microchemical Laboratory of the University of Geneva (for the determination of $\mathrm{C}$ and H) or by the Ilse Beetz Laboratory (96301 Kronach, Germany) for the determination of $\mathrm{P}$ and $\mathrm{Cl}$. Atomic absorption (AAS) analyses were performed with a Perkin-Elmer $1100 \mathrm{~B}$ spectrometer. IR spectra were obtained from KBr pellets with a Perkin-Elmer Spectrum One FT-IR spectrometer. The ES-MS spectra were obtained with a Finnigan SSQ 710C spectrometer using a capillary tempera-
\end{abstract}

Table 3. Stability constants of the complexes of $\mathrm{L}$ with $\mathrm{Co}^{\mathrm{II}}, \mathrm{Ni}^{\mathrm{II}}, \mathrm{Cu}^{\mathrm{II}}$ and $\mathrm{Zn}^{\mathrm{II}}$ in $\mathrm{CH}_{3} \mathrm{CN}$; $[\mathrm{L}]=10^{-4} \mathrm{M}$ and $[\mathrm{M}]=10^{-3} \mathrm{M}$

\begin{tabular}{lllllll}
\hline & $\mathrm{CoCl}_{2}$ & $\mathrm{NiCl}_{2}^{[\mathrm{a}]}$ & $\mathrm{Cu}\left(\mathrm{ClO}_{4}\right)_{2}$ & $\mathrm{CuCl}_{2}$ & $\mathrm{Zn}\left(\mathrm{ClO}_{4}\right)_{2}$ & $\mathrm{ZnCl}$ \\
\hline $\log K_{1}$ & $4.8 \pm 0.1$ & $4.9 \pm 0.1$ & $4.2 \pm 0.7$ & $5.0 \pm 0.1$ & $4.6 \pm 0.3$ & $5.4 \pm 0.2$ \\
\hline
\end{tabular}

${ }^{\text {[a] }}$ In $\mathrm{CH}_{3} \mathrm{CN} / \mathrm{CH}_{2} \mathrm{Cl}_{2}(97.1: 2.9, \mathrm{v} / \mathrm{v})$. 
ture of $200{ }^{\circ} \mathrm{C}$ and acceleration potential of $4.5 \mathrm{kV}$. The $10^{-5}-10^{-4}$ $\mathrm{M}$ solutions of the free ligand or its complexes dissolved in methanol were infused in a mixture of $\mathrm{CH}_{3} \mathrm{OH} / \mathrm{H}_{2} \mathrm{O} / \mathrm{HCOOH}$ (50:50:1, $\mathrm{v} / \mathrm{v}$ ) for the ligand, or pure $\mathrm{CH}_{3} \mathrm{CN}$ for the complexes. ${ }^{1} \mathrm{H}$ and ${ }^{31} \mathrm{P}\left\{{ }^{1} \mathrm{H}\right\}$ NMR spectroscopic data $\left(\left[\mathrm{D}_{6}\right] \mathrm{DMSO}\right.$ or $\left.\mathrm{CD}_{3} \mathrm{OD}\right)$ were collected with a Bruker AVANCE 400-DRX spectrometer (400 MHz) while EPR spectra of powdered samples were measured with a Bruker B-ER 420 spectrometer. Magnetic susceptibility measurements were performed with a MPMS5 SQUID susceptometer (Quantum Design Inc.) operating at a magnetic field strength of $1 \mathrm{kOe}$. Corrections for diamagnetism were estimated from Pascal constants. $^{[16]}$ Effective magnetic moments were calculated as $\mu_{\text {eff }}=$ $2.828\left(\chi_{\text {para }} \cdot T\right)^{1 / 2}$ where $\chi_{\text {para }}$ is the molar paramagnetic susceptibility of the metal ion.

Spectrophotometric Titrations: For the titrations with chloride salts $\mathrm{MCl}_{2} \cdot n \mathrm{H}_{2} \mathrm{O}(\mathrm{M}=\mathrm{Co}, \mathrm{Ni}, n=6 ; \mathrm{M}=\mathrm{Cu}, n=2 ; \mathrm{M}=\mathrm{Zn}, n=$ 0 ), the electronic spectra in the UV/Vis range were recorded at $298 \mathrm{~K}$ with a Perkin-Elmer Lambda-7 connected to an external computer, using quartz cells of $0.100 \mathrm{~cm}$ path length. Solutions were prepared in a thermostatted vessel (Metrohm 6.1418.220) kept under $\mathrm{Ar}$ and the titrant solution was added with an automated burette from Metrohm (6.1569.150 or.210) fitted with an anti-diffusion device. In a typical experiment, $50 \mathrm{~mL}$ of $\mathrm{L}\left(10^{-4} \mathrm{M}\right)$ was titrated with $10^{-3} \mathrm{M}$ solutions of $\mathrm{M}^{\mathrm{II}}$ salts. After each addition of $0.5 \mathrm{~mL}$ and a delay of $15 \mathrm{~min}$ to equilibrate the solution, the spectrum was measured and transferred to the computer. Alternatively, titrations with perchlorate salts $\mathrm{M}\left(\mathrm{ClO}_{4}\right)_{2} \cdot 6 \mathrm{H}_{2} \mathrm{O}(\mathrm{M}=\mathrm{Cu}, \mathrm{Zn})$ were performed with a J\&M diode array TIDAS II spectrometer using a thermostatted $\left(20.0 \pm 0.1{ }^{\circ} \mathrm{C}\right)$ glass-jacketed vessel filled with Ar. The starting volume was $25 \mathrm{~mL}$ and aliquots of the titrant $(0.2 \mathrm{~mL})$ were added using a Socorex ${ }^{\circledR}$ micropipette. The solvents used $\left(\mathrm{CH}_{3} \mathrm{CN}, \mathrm{CH}_{2} \mathrm{Cl}_{2}\right)$ were of spectroscopic grade and purchased from Fluka AG (Buchs, Switzerland). Acetonitrile was dried with molecular sieves ( $3 \AA$ ) and the solutions were stored under argon. The metal-ion content was determined by AAS after decomposition of the samples in boiling $60 \% \mathrm{HClO}_{4}$, or, in the case of 5 , by complexometric titration with $\mathrm{H}_{2} \mathrm{edta}^{2-}$ in the presence of xylenol orange and urotropine. The phosphorus content of some samples was determined spectrophotometrically using the phosphomolybdate method. ${ }^{[17]}$

\section{Preparation of the Complexes}

$\mathrm{CoL}\left(\mathrm{ClO}_{4}\right)_{2} \cdot \mathbf{2 H}_{2} \mathrm{O}$ (1): An ethanolic solution (1 mL) of $\mathrm{Co}\left(\mathrm{ClO}_{4}\right)_{2} \cdot 2 \mathrm{H}_{2} \mathrm{O}(0.0292 \mathrm{~g} ; 0.0798 \mathrm{mmol})$ was slowly added to $3 \mathrm{~mL}$ of a solution of $\mathrm{L}(0.1000 \mathrm{~g} ; 0.0957 \mathrm{mmol})$ in EtOH $(3 \mathrm{~mL})$, at room temp. and under constant stirring. A light blue precipitate formed immediately. The reaction mixture was stirred for $8 \mathrm{~h}$. and the precipitate was centrifuged, washed repeatedly with ethanol and dried under high vacuum over $\mathrm{P}_{4} \mathrm{O}_{10}$ for $4 \mathrm{~h}$. Yield $0.1029 \mathrm{~g}(99 \%)$. $\mathrm{C}_{56} \mathrm{H}_{84} \mathrm{Cl}_{2} \mathrm{CoO}_{16} \mathrm{P}_{4} \cdot 2 \mathrm{H}_{2} \mathrm{O}$ (1303.0): calcd. C 51.62, $\mathrm{H} \mathrm{6.81,} \mathrm{Cl} 5.44$, Co 4.52, P 9.51; found C 52.05, H 6.87, Cl 5.39, Co 4.59, P 9.74.

$\mathrm{NiL}\left(\mathrm{ClO}_{4}\right)_{2} \cdot \mathbf{2} \mathbf{H}_{2} \mathrm{O}$ (2): A solution of $\mathrm{Ni}\left(\mathrm{ClO}_{4}\right)_{2} \cdot 6 \mathrm{H}_{2} \mathrm{O}(0.0292 \mathrm{~g}$; $0.0797 \mathrm{mmol}$ ) in $1 \mathrm{~mL}$ of ethanol was added dropwise at constant stirring and ambient temperature to a solution of $\mathrm{L}(0.1000 \mathrm{~g}$; $0.0957 \mathrm{mmol}$ ) in $2 \mathrm{~mL}$ ethanol. The reaction mixture was stirred for $10 \mathrm{~h}$; the resulting, pale-yellow precipitate was centrifuged, washed repeatedly with ethanol and dried under high vacuum for $4 \mathrm{~h}$. Yield $0.0888 \mathrm{~g}(85 \%) . \mathrm{C}_{56} \mathrm{H}_{84} \mathrm{Cl}_{2} \mathrm{NiO}_{16} \mathrm{P}_{4} \cdot 2 \mathrm{H}_{2} \mathrm{O}$ (1302.83): calcd. C 51.63, $\mathrm{H}$ 6.81, Cl 5.44, Ni 4.51, P 9.51; found C 51.60, H 6.80, Cl 5.59, Ni 4.18, P 9.48.

$\mathrm{CuL}\left(\mathrm{ClO}_{4}\right)_{2} \cdot \mathbf{4 H}_{\mathbf{2}} \mathrm{O}$ (3): An ethanolic solution (1 mL) of $\mathrm{Cu}\left(\mathrm{ClO}_{4}\right)_{2} \cdot 7 \mathrm{H}_{2} \mathrm{O}(0.0186 \mathrm{~g} ; 0.0478 \mathrm{mmol})$ was slowly added to
$1.5 \mathrm{~mL}$ of a solution of $\mathrm{L}(0.0500 \mathrm{~g} ; 0.0478 \mathrm{mmol})$ in $\mathrm{EtOH}$, at room temp. and under constant stirring. A lemon-yellow precipitate formed immediately. The reaction mixture was stirred for $8 \mathrm{~h}$. The resulting precipitate was centrifuged, washed repeatedly with ethanol and dried under high vacuum over $\mathrm{P}_{4} \mathrm{O}_{10}$ for $4 \mathrm{~h}$. Yield $0.0513 \mathrm{~g}(82 \%) . \mathrm{C}_{56} \mathrm{H}_{84} \mathrm{Cl}_{2} \mathrm{CuO}_{16} \mathrm{P}_{4} \cdot 4 \mathrm{H}_{2} \mathrm{O}$ (1307.7): found $\mathrm{C} 50.06$, H 6.90, Cl 5.33, P 9.25; calcd. C 49.88, H 6.55, Cl 5.28, P 9.22.

$\mathrm{CuLCl}_{2} \cdot \mathbf{4} \mathrm{H}_{2} \mathrm{O}$ (4): An ethanolic solution of $\mathrm{CuCl}_{2} \cdot 2 \mathrm{H}_{2} \mathrm{O}(0.0272 \mathrm{~g}$; $0.1595 \mathrm{mmol} ; 0.5 \mathrm{~mL}$ was added dropwise to $1 \mathrm{~mL}$ of an ethanolic solution of $\mathrm{L}(0.2000 \mathrm{~g} ; 0.1914 \mathrm{mmol})$ at constant stirring and room temp. A few minutes after being mixed, an intensely yellow precipitate formed. The complex was centrifuged, washed repeatedly with ethanol and dried under high vacuum over $\mathrm{P}_{4} \mathrm{O}_{10}$ for $4 \mathrm{~h}$. Yield $0.1102 \mathrm{~g} \mathrm{(57 \% ).} \mathrm{C}_{56} \mathrm{H}_{84} \mathrm{Cl}_{2} \mathrm{CuO}_{8} \mathrm{P}_{4} \cdot 4 \mathrm{H}_{2} \mathrm{O}$ (1215.7): found $\mathrm{C}$ $54.95, \mathrm{H} 7.28, \mathrm{Cl} 5.96, \mathrm{Cu} 5.54, \mathrm{P} 10.12$; calcd. C 55.33, H 7.63, $\mathrm{Cl}$ 5.83, Cu 5.22, P 10.19.

$\mathrm{ZnL}\left(\mathrm{ClO}_{4}\right)_{2} \cdot \mathbf{2} \mathrm{H}_{2} \mathrm{O}$ (5): A solution of $\mathrm{Zn}\left(\mathrm{ClO}_{4}\right)_{2} \cdot 6 \mathrm{H}_{2} \mathrm{O}(0.0323 \mathrm{~g}$, $0.0869 \mathrm{mmol})$ in ethanol $(1.2 \mathrm{~mL})$ was added dropwise to a solution of $\mathrm{L}(0.1035 \mathrm{~g}, 0.0956 \mathrm{mmol})$ in ethanol $(0.5 \mathrm{~mL})$ at constant stirring and room temp. The prepared reaction mixture was stirred for $12 \mathrm{~h}$. The white precipitate formed was separated by centrifugation and washed repeatedly with ethanol and dried under high vacuum at $60{ }^{\circ} \mathrm{C}$ for $15 \mathrm{~h}$. Yield $0.1160 \mathrm{~g}$ (quantitative). $\mathrm{C}_{56} \mathrm{H}_{84} \mathrm{Cl}_{2} \mathrm{O}_{16} \mathrm{P}_{4} \mathrm{Zn} \cdot 2 \mathrm{H}_{2} \mathrm{O}$ (1309.5): found $\mathrm{C} 51.67, \mathrm{H} \mathrm{6.78,} \mathrm{Cl} 5.44$, P 9.46, Zn 5.05; calcd. C 51.36, H 6.77, Cl 5.44, P 9.46, Zn 4.99.

$\mathbf{Z n}_{\mathbf{2}} \mathbf{L} \mathbf{C l}_{\mathbf{4}}$ (6): An ethanolic solution $(1 \mathrm{~mL})$ of $\mathrm{ZnCl}_{2}(0.0237 \mathrm{~g}$; $0.1739 \mathrm{mmol}$ ) was added dropwise to $2 \mathrm{~mL}$ of an ethanolic solution of L (0.2000 g; $0.1913 \mathrm{mmol})$, while stirring and the prepared mixture was stirred at room temp. for a further $10 \mathrm{~h}$. The white precipitate obtained was centrifuged, washed repeatedly with ethanol and dried under high vacuum over $\mathrm{P}_{4} \mathrm{O}_{10}$ for $30 \mathrm{~h}$. Yield $0.1050 \mathrm{~g}(94 \%)$. $\mathrm{C}_{56} \mathrm{H}_{84} \mathrm{Cl}_{4} \mathrm{O}_{8} \mathrm{P}_{4} \mathrm{Zn}_{2}$ (1281.76): found $\mathrm{C} 52.53, \mathrm{H}$ 6.77, $\mathrm{Cl} 11.16, \mathrm{P}$ 9.95, Zn 10.24; calcd. C 52.48, H 6.60, Cl 11.06, P 9.66, Zn 10.20.

Crystal Structure of 6: Crystals have been obtained by slow concentration of a methanol solution of $\mathrm{L}$ and $\mathrm{ZnCl}_{2}$ (each dissolved in $10^{-3} \mathrm{M}$ ). Data collection was performed at $140 \mathrm{~K}$ with a marresearch mar345 IPDS. Data reduction was carried out with CrysAlis RED, release 1.7.0. ${ }^{[18]}$ An empirical absorption correction was applied to the data set. ${ }^{[19]}$ Structure solution and refinement as well as molecular graphics and geometrical calculations were performed with the SHELXTL software package, release 5.1.[20] The structures were refined using the full-matrix least squares on $F^{2}$ with all non- $\mathrm{H}$ atoms anisotropically defined. $\mathrm{H}$ atoms were placed in calculated positions using the "riding model" (except those belonging to water molecules, which were not included in the final model) and fixing their $U_{\text {iso }}$ to $0.08 \AA^{2}$. The crystals are triclinic, space group $P \overline{1}, Z=2$, with $a=16.033(8) \AA, b=16.654(7) \AA, c=$ 26.727(17) $\AA, \alpha=100.07(4)^{\circ}, \beta=93.18(5)^{\circ}, \gamma=95.07(4)^{\circ}$. CCDC219688 contains the supplementary crystallographic data for this paper which can be obtained free of charge at www.ccdc.cam.ac.uk/ conts/retrieving.html [or from the Cambridge Crystallographic Data Centre, 12 Union Road, Cambridge CB2 1EZ, UK; Fax: (internat.) + 44-1223-336-033; E-mail: deposit@ccdc.cam.ac.uk].

\section{Acknowledgments}

The authors thank Assoc. Prof. Dr. Elena Russeva for her help in the determination of the phosphorus contents, Dr. Lucia Bonomo and Dr. Geoffroy Guillemot for magnetic susceptibility measurements, Dr Vittorio Esposito for a gift of p-tert-butylcalix[4]arene, and Dr. Natacha Guérin for collecting some of the NMR spectro- 
scopic data. This work was supported through a grant from the Swiss National Science Foundation (Project SCOPES 7BUPJ062293.00/1).

[1] Calixarenes 2001 (Eds.: Z. Asfari, V. Böhmer, J. Harrowfield, J. Vicens), Kluwer Academic Publ., Dordrecht, 2001.

[2] Calixarenes for Separations (Eds.: G. J. Lumetta, R. D. Rogers, A. Gopalan), ACS Symposium Series, American Chemical Society, Washington D. C., 2000, vol. 757.

[3] M. P. O. Wolbers, F. C. J. M. Vanveggel, F. G. A. Peters, E. S. E. Vanbeelen, J. W. Hofstraat, F. J. Geurts, D. N. Reinhoudt, Chem. Eur. J. 1998, 4, 772-780.

[4] F. de M. Ramirez, S. Varbanov, C. Cécile, G. Muller, N. FatinRouge, R. Scopelliti, J.-C. G. Bünzli, J. Chem. Soc., Dalton Trans. 2002, 4505-4513.

[5] [5a] C. Wieser-Jeunesse, D. Matt, M. R. Yaftian, M. Burgard, J. M. Harrowfield, C. R. Acad. Sci. Paris, Ser. IIC 1998, 1, 479-502. ${ }^{[5 b]}$ S. Barboso, M. A. G. Carrera, S. E. Matthews, F. Arnau-Neu, V. Böhmer, J. F. Dozol, H. Rouquette, M. J. Schwing-Weill, J. Chem. Soc., Perkin Trans. 2 1999, 719-723. ${ }^{[5 c]}$ A. Arduini, V. Böhmer, L. Delamu, J.-F. Desreux, J.-F. Dozol, M. A. G. Carrera, B. Lambert, C. Musigmann, A. Pochini, A. Shivanyuk, F. Ugozzoli, Chem. Eur. J. 2000, 2135-2144. [5d] S. E. Matthews, P. Parzuchowski, A. Garcia-Carrera, C. Gruttner, J. F. Dozol, V. Böhmer, Chem. Commun. 2001, 417-18. [5e] Yu. I. Rudzevich, A. B. Drapailo, V. L. Rudzevich, V. I. Miroshnichenko, V. I. Kalchenko, I. V. Smirnov, V. A. Babain, A. A. Varnek, G. Wipff, Russ. J. Gen. Chem. 2002, $72,1736-1742$

[6] J. M. Harrowfield, "Metal Ions in Biological Systems" in The Lanthanides and Their Interrelations With Biosystems (Eds.: A. Sigel, H. Sigel), M. Dekker Inc., New York, 2003, vol. 40, chapter 4.

[7] [7a] P. Molenved, J. F. J. Engbersen, D. N. Reinhoudt, Chem.
Soc. Rev. 2000, 29, 75-86. ${ }^{[7 b]}$ H. Ma, Q. Ma, M. Su, L. Nie, H. Han, S. Xiong, B. Xin, G. Liu, New. J. Chem. 2002, 26, $1456-60 .{ }^{[7 \mathrm{c}]}$ I. A. Bagatin, E. S. de Souza, A. S. Ito, H. E. Toma, Inorg. Chem. Commun. 2003, 6, 288-293.

${ }^{[8]}{ }^{[8 a]}$ F. de M. Ramirez, L. J. Charbonnière, G. Muller, R. Scopelliti, J.-C. G. Bünzli, J. Chem. Soc., Dalton Trans. 2001, 3205-3213. ${ }^{[8 b]}$ F. de M. Ramirez, L. J. Charbonnière, G. Muller, J.-C. G. Bünzli, Eur. J. Inorg. Chem., in press. ${ }^{\left[{ }^{[c]} \mathrm{L}\right.}$. Le Saulnier, S. Varbanov, R. Scopelliti, M. Elhabiri, J.-C. G. Bünzli, J. Chem. Soc., Dalton Trans. 1999, 3919-3925.

${ }^{[9]}$ G. B. Deacon, J. H. S. Green, Spectrochim. Acta, Part A 1968, $24,845-852$.

${ }^{[10]}$ G. Borisov, S. Varbanov, L. M. Venanzi, A. Albinati, F. Demartin, Inorg. Chem. 1994, 33, 5430-5437.

${ }^{[11]}$ C. M. Mikulski, L. L. Pytlewski, N. M. Karayannis, Synth. React. Inorg. Met.-Org. Chem. 1979, 9, 401-408.

${ }^{[12]}$ B. N. Figgis, J. Lewis, Prog. Inorg. Chem. 1964, 6, 37-222.

${ }^{[13]}$ F. A. Cotton, G. Wilkinson, Advanced Inorganic Chemistry, 5th ed., Wiley Interscience, New York, 1988.

${ }^{[14]}$ H. Gampp, M. Maeder, C. J. Meyer, A. D. Zuberbühler, Talanta 1985, 23, 1133-1139.

${ }^{[15]}$ K. N. Raymond, Chem. Eng. News 1983, 61, 4.

${ }^{[16]}$ L. N. Mulay in Theory and Applications of Molecular Paramagnetism (Eds.: E. A. Boudreaux, L. N. Mulay), John Wiley \& Sons, New York 1976, p. 491-495.

${ }^{[17]}$ S. G. Varbanov, E. D. Russeva, N. N. Nikolov, Bulg. Chem. Commun. 1999, 26, 91-97.

[18] Oxford Diffraction Ltd., Abingdon, Oxfordshire, UK, 2003.

${ }^{[19]}$ DELABS: N. Walker, D. Stuart, Acta Crystallogr., Sect. A 1983, 39, 158-166.

${ }^{[20]}$ G. M. Sheldrick, University of Göttingen, Germany, 1997; Bruker AXS, Inc., Madison, Wisconsin 53719, USA, 1997.

Received November 20, 2003

Early View Article

Published Online April 6, 2004 